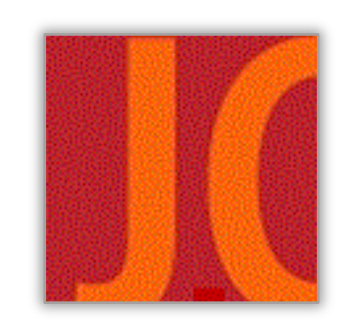

\title{
Gifting a Healing Education Through Writing Life and Art: A Paris Studio Residency
}

\author{
Nané Jordan \\ $\boldsymbol{B}$ \\ Barbara Bickel
}

\begin{abstract}
:
We are two Canadian arts-based educational researchers who collaborated during a studio residency in Paris, France, during May 2015, for ten days. Our residency curriculum included study of feminist poet-thinker Hélène Cixous, taking walks in Paris locales, viewing women's art, and engaging arts-based inquiry methods such as journaling, life writing and creative embodied practices, as a way to pay attention to and document our daily experiences. We practiced what we call companion pedagogy, with a feminist focus on mothering and gifting relations. We find that arts-based, restorative practices strengthen our wellbeing and resiliency as educators, and also support our desire for a more nurturing, mothering humanity to come forward for gifting a healing education. Healing education begs the question of how to address the resiliency of educators over time through what are increasingly challenging and depleting conditions of institutional cultures and economies. We thus offer creative practices such as studio residencies for collective care and gifting that can nurture a restorative pacing of life, while supporting the resiliency of educators to gift their energies towards creative curriculum visioning and enacting of social change.
\end{abstract}

Keywords: companion pedagogy; mothering and gifting relations; healing education 


\section{Offrir une éducation de guérison par l'écriture et l'art : une résidence en atelier à Paris}

\section{Résumé :}

Nous sommes deux chercheurs canadiens en éducation, spécialistes des Arts qui avons collaboré lors d'une résidence en studio de 10 jours à Paris, en France, en mai 2015. Notre programme de résidence traitait de l'étude de la penseuse et poétesse féministe Hélène Cixous, ainsi que de ballades dans les avenues parisiennes, de la contemplation de l'art de femmes, en se servant de méthodes d'enquête artistiques comme la journalisation, la biographie et des pratiques incarnées créatives, comme moyen de prêter attention et de documenter nos expériences quotidiennes. Nous avons pratiqué ce que nous appelons la pédagogie d'accompagnement, avec un angle féministe sur les relations maternelles et de don. Nous avons constaté que les pratiques restauratrices basées sur les arts, renforcent le bien-être et la résilience en tant qu'éducateurs, et confirment également notre souci pour une humanité plus maternelle et nourricière afin d'obtenir une éducation par la guérison. L'éducation par la guérison soulève la question de savoir comment aborder la résilience des éducateurs au fil du temps dans les conditions de plus en plus difficiles et épuisantes des cultures et des économies institutionnelles. Nous offrons ainsi des pratiques créatives comme les résidences en studio pour une prise en charge et des dons collectifs pouvant contribuer à un rythme restaurateur de vie en appuyant la résilience des éducateurs à orienter leurs énergies vers des programmes créatifs de vision et de mise en œuvre du changement social.

Mots clés : pédagogie d'accompagnement; relations maternelles; relations de don; éducation de guérison 


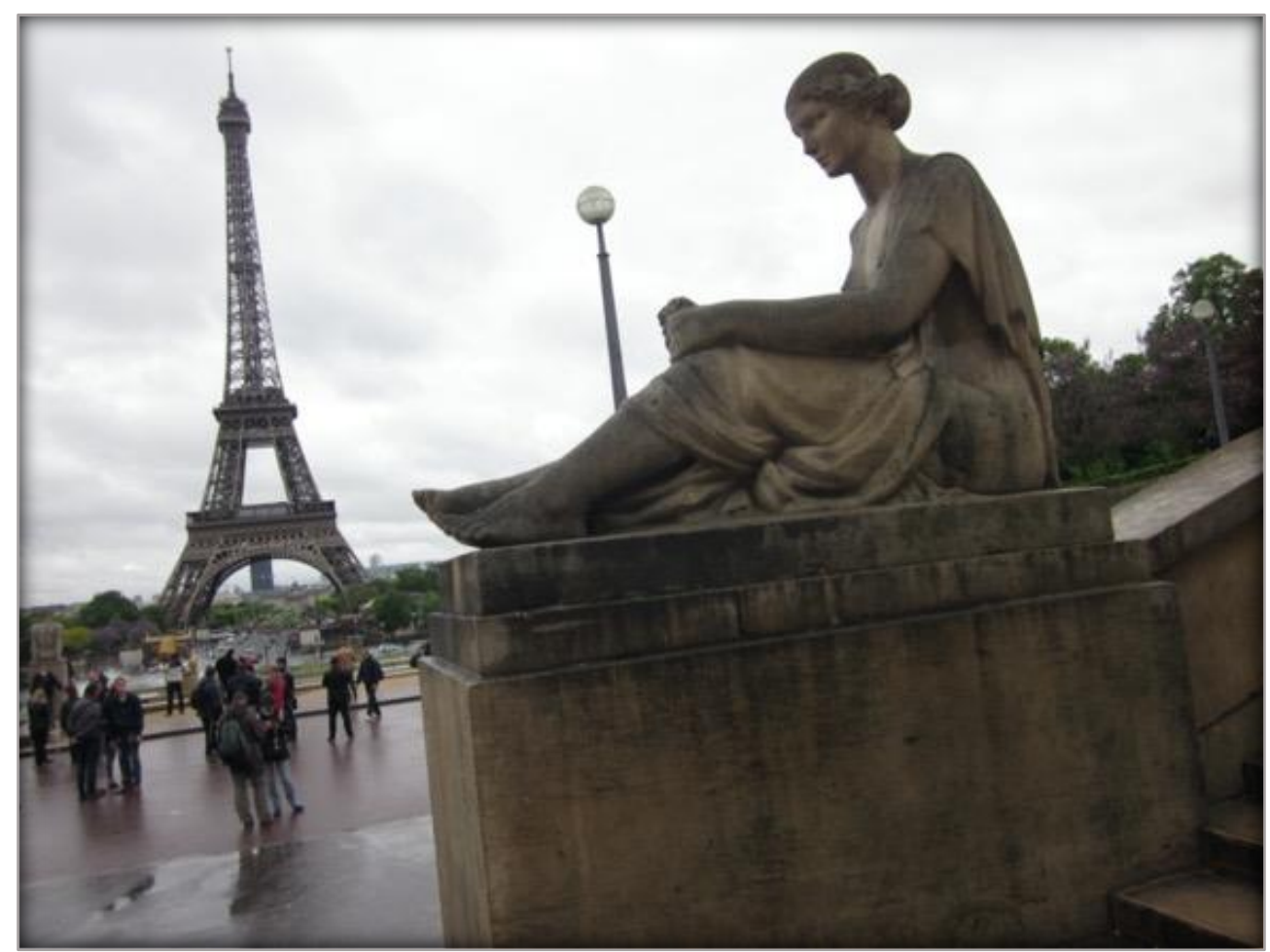

View of the Eiffel Tower from the Trocedero, Paris. Photo by Nané.

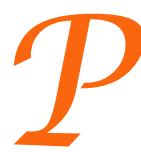

aris is an historical and contemporary locale for working artists and writers, who come from all over the world to develop their practices. We, Nané and Barbara, are two Canadian artsbased education researchers who collaborated during a studio residency in Paris, France. ${ }^{1}$

This essay shares life writing, artful images and themes that grew from our ten-day residency in 2015. For purposes of introducing the themes and means of this residency, we will shift between a writing voice of "we" to noting ourselves by name when describing our individual backgrounds.

Nané invited Canadian artist-teacher-researchers to join her at the University of Paris 8, France, in life writing and artful practices, as part of her arts-based, postdoctoral research on the life writing of the French-Algerian poet-thinker Hélène Cixous. Cixous, known as one of the French feminists, is a writer, literary theorist and educational innovator residing in Paris, France. Cixous' oeuvre includes feminist literary and poetic-theoretic essays, novels and theatre pieces. She is most famous in North America for her 1976-translated essay "The Laugh of the Medusa", and her notion of écriture feminine. In this, she urges women to reclaim their lives from the phallic repressions of patriarchal society, to creatively script themselves as central subjects of writing and art, and to defy normative conventions while creating new forms of expression.

\footnotetext{
${ }^{1}$ An earlier version of the paper was presented at CSSE University of Calgary, May 29-June 1, 2016, ARTS Researchers and Teachers Association. We had a one-hour session, and introduced participants to our MA Pose practice after we presented this paper with visual slides.
} 
In the context of postdoctoral studies, Nané specifically explored Cixous' use of maternal generative processes, especially birth-giving subjectivity, as the basis for new conceptions of artsbased research and writing life. While this essay does not detail this research, it draws from it through focusing on women's art-making and writing, and the gifting embodiment of mothering.

Nané was drawn to the history and impetus of the University of Paris 8, combined with the provocative writing of Hélène Cixous, as a nexus for socially transformative research. As a community activist, collaborative researcher, mother, author and artist, Nané is compelled by circumstance and commitment to work towards social change in community with others through what is known as the gift economy (Vaughan, 1997, 2007). ${ }^{2}$ Nané viewed the funding for postdoctoral studies in France through a gift-centred lens, and envisioned sharing Paris and the post-1968 French academy with others, by extending the gift of her locale through a studio residency.

Nané's background includes working for many years in women's health advocacy, specifically in the area of reclaiming midwifery for mothers' birth-giving care and quality of experience. She advocated for and provided grassroots midwifery and doula services, before undertaking graduate studies in women's spirituality, and subsequently exploring the emergent, artful, educational and curriculum impacts of such for "inspiriting the academy" (Jordan, 2011). Nané's arts-based educational research grew from using storytelling, autobiography and life writing as feminist research methods, and from a desire to explore the provocative life writing of Hélène Cixous in situ. Additionally, Nané's postdoctoral studies were rooted in the gift of having been a research assistant with Canadian life writing, arts-based curriculum scholars, Erika Hasebe-Ludt, Carl Leggo and others (Hasebe-Ludt et al., 2009; Chambers et al., 2012). This organic network of relations nurtured Nané's desire to continue her creative educational research in France, with a focus on Cixous' texts, feminist life writing themes and birth-based philosophies (Jordan, 2016, 2018, 2019).

Nané was supported in her research at the University of Paris 8, in the Department of Gender Studies. ${ }^{3}$ Paris 8 was co-founded by Hélène Cixous in 1968, as a direct response to the infamous events of May 1968 in France-a student uprising, with its epicenter in Paris, that inspired a workers' revolt and turned into a period of volatile civil unrest. The revolt included demonstrations, massive general strikes and days of student-led street battles with police in the Latin Quarter. Protestors called for radical changes in the paternalistic, authoritarian socio-political hierarchies of post-World War II France. As an educational response, the University of Paris 8 initiated experimental student-

\footnotetext{
${ }^{2}$ The maternal gift economy refers to the freely given gifts of mothers towards children in a one-way, unilateral flow of gifting that fulfills children's needs for nourishment, shelter, attention, growth and love. The gift economy denotes gift giving as the foundation of life, wherein gifts of work, service, time or attention are freely given from one person to another, without expectation of reward by virtue of the inherent value of those receiving gifts. Yet gifts are most often ignored or dominated by destructive market systems of exchange economies, wherein resources as gifts (of the Earth, mothers and others, in goods and labour) are sequestered for the profit of few at the expense and deprivation of wellbeing for many. See Genevieve Vaughan in the reference list.

${ }^{3}$ Nané's arts-based study of the texts of Hélène Cixous at the University of Paris 8, was funded by the Social Sciences and Humanities Research Council of Canada as a Postdoctoral Fellowship from 2014-2016. Nané acknowledges and thanks SSHRC for this vital funding, and Le centre d'études féminines at Paris 8 , in particular Professor MarieDominique Garnier, for supporting the red threads of her research throughout and beyond this time period. Nané's postdoctoral study is titled: Writing Life with Hélène Cixous: Expanding the Art of Educational Inquiry.
} 
centred pedagogy and research in the humanities and social sciences, influenced by left-leaning politics and the development of post-structuralist thought of 1970s France. The freethinking legacy of Paris 8 included the teaching careers of philosophers Gilles Delueze and Michel Foucault. Feminist philosophy and studies were hard-won grounds as Hélène Cixous established "Le centre d'études féminines" in 1974 and thereafter worked to retain the centre-now a fully-fledged Department of Gender Studies at Paris 8.

Though already present in Nané's feminist birth-work and research as a transformative educational theme, the notion of "healing" in personal and collective spheres emerged from her own recent experiences of illness-including experiencing limiting fatigue known as burnout. Author Lucy Pearce notes this as an archetypal "burning" of women's power and energies (2016). This is especially so for women who are over-working in multiple ways as workers, mothers, caregivers and gift-givers for others, leading to a new epidemic of chronic illness (Pearce, 2018). Prior to living in France, Nané recognized the culture of over-work and fatigue around her, while trying to manage the limits of her own body and mind. She experienced how working in the academy in alternative ways can take a toll, even if one's work is based on inspiration and passion. This begs the question of how to address the resiliency of educators over time, through what are increasingly challenging, depleting conditions of institutional cultures and economics. Nané continues to seek solutions for collective care and gifting that nurtures all-through a restorative pacing of life. Beyond notions of "self care", more is needed for collective social, educational and institutional change that honours educators' needs for restoration in community with others.

Thus, as a part of restorative and gifting pathways, Nané's aims were to provide education scholars an opportunity for creative development in the city of Paris, and to increase networks for emergent ideas in arts-based, life writing educational research. Her Paris proposal was ultimately taken up by her long-time collaborator in arts education and in socially engaged art and feminist spirituality, ${ }^{4}$ Barbara, who arrived to stay for a ten-day residency. Barbara was already in Europe during this time period, completing her own sabbatical year. Thus began a gift of space to create, write, rest and walk through historical streets, museums and cathedrals in Paris, drawing from the consciousness of this vital city and from the nurturing roots of shared life commitments and scholarly work.

Important to the lens of our collaborative inquiry were our combined commitments to the field of women's and gender studies, in the context of Nané's study of Hélène Cixous' feminist texts. We, Nané and Barbara, had previously co-created artistic and contemplative curriculum practices through the field of feminist spirituality for many years, and continue to collaborate through a women's art

\footnotetext{
${ }^{4}$ Feminist spirituality, also known as women's spirituality, is a world-wide grassroots, activist and scholarly movement that empowers women's spiritual authority, cultural leadership, diverse spiritual practices and experiences. Feminist spirituality uplifts women as change makers and leaders throughout the ages, in patriarchal and pre-patriarchal societies. Growing from women's activism and scholarship from the 1970s onwards, feminist spirituality engages with the spiritual lives of women, with feminist critiques of patriarchal, male-centred religions, and with the emergence of alternative spiritual streams that are women-centred, inclusive of the divine female/feminine, Goddess(es) and Earthbased wisdom.
} 
collective we co-founded called Gestare. ${ }^{5}$ Gestare also functions through the gift economy, where we gift our time, presence and creative capacities to each other and our communities. As such, we decided to use our Paris locale to delve further into the past and present of women artists' lives through art exhibitions and our own arts-based and spiritual feminist practices.

Barbara is an artist and scholar whose early background in the social service sector of rehabilitation led her to pursue collaborative art as a healing practice. As a full-time artist, Barbara's early experiences of collaborative art practices instilled her belief in the significance of community to creatively take on the issues, struggles and passions of our lives with others, and not in isolation. As a feminist pedagogue teaching art and education in higher education, she found herself at odds with the constraints of the standardization of curriculum for teachers in training. When the opportunity to take on the Directorship of the Women, Gender and Sexuality Studies program at the University of Illinois, Carbondale, was offered, Barbara entered this role as a feminist artist educator with the desire to create emancipatory, critical and nourishing curriculum programming and support for students and faculty across campus.

Through Barbara's administrative role, she had freedom to lead and create, while also working within the constraints of an economically struggling region and university system in the southern mid-west of the United States. Working to sustain health in an institution that is suffering from systemic scarcity and perpetual erosion of faculty and student morale takes its toll on ones' physical and mental health. The gift of a sabbatical to restore herself through collaborative creative research with others internationally offered a chance to step outside of her insular university world and gain wider perspectives, while at the same time nourishing her artist self. This dual experience invited the reframing of Barbara's personal life experiences through connecting with global struggles.

At the time of our residency in 2015, Barbara was steeped in living and working through what she felt were the effects of an alarming regression in American politics, as well as in the $\mathrm{K}-16$ educational system in the United States. After retiring from her position in 2017, she witnessed the deterioration of the very program she had led. Together, we believe such regression points to the ongoing need for social justice in gender-, race-, sex-, and class-informed teaching, learning and research. We posit that gifting a healing education acknowledges the need for social justice transformation, with access to resources and wellbeing for all. This includes supporting the resiliency and capacity of educators to gift their energies towards creative visioning and enacting of social change.

\footnotetext{
${ }^{5}$ The Gestare Art Collective is currently a group of four women artists dedicated to process-based, Earth-focused, embodied collaborative artistic practices. We hold dialogue and care in relationship with each other as a core practice for discerning our art forms. Our embodied methods include labyrinth walking, story sharing, sounding, communal napping, poetic writing, trance, ritual, textiles, visual and performance arts. We are informed by women's spirituality, the divine female/feminine and gestating connections with Mother Earth. "Gestare" is the Latin root-word of "gestation", meaning to carry within the womb. For more information, see http://www.gestareartcollective.com/
} 


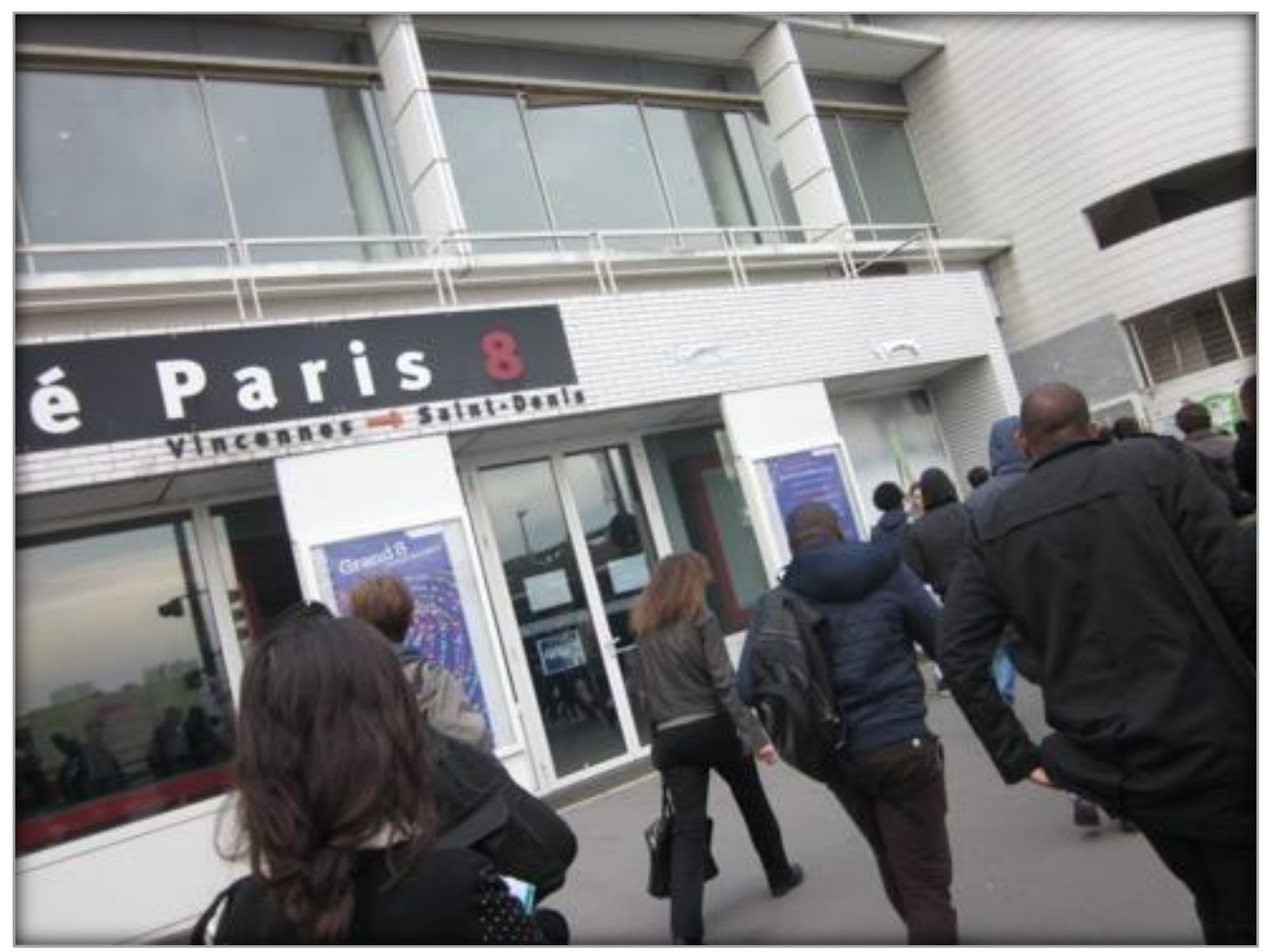

Students entering the University of Paris 8, Paris. Photo by Nané.

\section{Healing Education, Companion Pedagogy: Studio Methods and Themes}

There is an appreciation for bodied-life in France, where sensuality, quality food and time spent with others has value and place. This is perhaps the "gifting" side of a culture that invites you to stop and savour life with others, especially when sitting at one of Paris' many ubiquitous cafés. Yet Paris can also feel like a busy, impersonal Metropolis that you might get lost in while navigating your way. Based in the gifts and tensions of this locale, we had much "data" to draw from in the many stops we made along the way.

As artists and researchers, this residency was a time away from the obligations of regular life to focus on restoration and re-finding ourselves. Artist residencies are traditionally a time to reflect upon and expand artistic practices in new or different locales, for a period of time, away from one's regular life. During our residency, we deepened our relationship with each other by focusing on nourishing routines and delving into creative research to experiment with new methods. We lived our understanding of curriculum as a continuum of inner and outer work, a nourishing flow or duet between self and other, teacher and student through the currere of education (Pinar \& Grumet, 1976). It takes an informed, insightful self to lead and teach others, to do this well with meaning and impact. We have come to understand that when one's body or self is depleted, we need to nurture and restore ourselves in order to continue to nourish others in vital ways. We propose that studio residencies, such as we co-created in Paris, can happen anywhere, including close to home, to support the resiliency and capacity of educators to do the important work of teaching others. 
The finding and re-finding of selves is also a compelling theme in Hélène Cixous' writing, where Cixous engages feminine birth-giving metaphors to describe the creative process of writing as a process of self-making and regeneration (Jordan, 2016). Subjectivity, in regards to formations of the personal and social "I", can be viewed as a living site of ever-transforming, birthing potential. As said in the words of Cixous, through the creative process of writing and art, I can "give birth to myself and ... nurse myself, too. Life summons life" (Cixous, 1977/1991, p. 31).

From this regenerative vein of thought, we nourished ourselves by engaging the art of life writing to document our journey. Using life writing was an important tool for paying attention to birthing and nursing "myselves" à la Cixous. Life writing can be a path of self-awareness and insight, of noticing what matters in the art of daily life. In this way, reading and writing life expands knowledge and empathy, a "heart of wisdom" for learning to live well, through fields such as arts and literacy education, curriculum studies and philosophy of education (Hasebe-Ludt \& Jordan, 2010; Chambers et al., 2012). Life writing is crafted through written texts and can be conveyed through visual artistic practices and all means of creative expression. As noted by Canadian curriculum scholar and life writer Cynthia Chambers, writing our lives is "wayfinding" that models an "education of attention" (2008, p. 119) where we might not know our own stories otherwise.

We thus propose that telling and writing our stories while reading the stories of others is a key curriculum element in what we are calling "healing education". Healing is a life-giving and gifting process (not a pill), undertaken over time in relationship with others. We view education as depending upon a flowing, fluid duet of inner and outer curriculum work, from self towards another and back again as interdependent beings. Paying attention to this flow and its subtle resources, we can recognize and support what is depleted, and nourish what needs attention, repair or letting go. Given the many traumas at work in lives impacted by ongoing injustices both interpersonal and social, we find that the next stage of curricular, educational and social evolution needs to be a relational and healing one.

The word "healing" is etymologically sourced from the words "holy" and "whole". Healing occurs in acknowledging one's own life as sacred, and all lives as sacred, while restoring each other towards wholeness. Healing education nurtures holistic, human, social and ecological interconnectedness, and draws from love itself. From this perspective, to empathically share stories is a radical curriculum practice that explores interlinking experiences of human trauma and resiliency in being both "I" and "we" as linked identities in our communities, schools and homes-in all places of life, learning and work. Story sharing can lead to healing as a relational practice of deep listening to each other, while learning to tell and write about what is important in our lives. The life writing of Hélène Cixous (1975/1976, 2007/2009, 2009/2012), particularly, moves across themes of love and relationship in daily life, informed by social forces of migration, colonialism, exile, gender, death, birth and home. Like the University of Paris 8 itself, life writing is a post-structuralist intervention. We would characterize both as going beyond fixed notions of curriculum and neo-liberal imperatives that instrumentalize education and deprive curriculum of the unique personhood of students and teachers (Pinar, 2006). As life writers, we seek to understand our lives and the field of education creatively through organic, life-giving, life-gifting, life-writing relations. 
In the context of our particular interests, our daily studio residency routine included paying attention to historical and contemporary women artists and writers, such as Hélène Cixous herself, as well as Carol Rama, whose art we discovered for the first time in a Paris exhibition. ${ }^{6}$ We followed feminist/feminine threads, growing from our desire for a more nurturing, mothering humanity to come forward. We understand mothering as more than a "personal" practice, rather, as an impetus for gifting regenerative relations of care. In this mother-work, during our residency, we developed a matricentric (mother-centred) art practice called "MA poses", which you will read of herein.

We locate ourselves in what motherhood studies scholar Andrea O'Reilly names "matricentric feminism" (2016), a "mother-centred model of feminism" (p. 3) that extends and transforms practices of mothering beyond limiting and oppressive conditions of patriarchal motherhood. Matricentric feminism recognizes how mothering has been socially and historically constructed by male-centred power and control (p. 4). Empowered mothering can become a life practice with personal and social agency, rather than a naturalized, unquestioned identity. Practicing mothering and nurturing beyond patriarchy requires family, community, institutional and economic collaborations of care. In the context of our inquiry, we playfully suggest the notion of "Mother writ large" as "a double figure who occupies both life and art—the progenitor and birth-giver of both" (Jordan, 2016, p. 99).

Throughout our residency, we paid attention to ourselves holistically through mind, emotions, body and spirit, in order to fully value ourselves, each other and the life-stories that matter to us in this time. In doing so, we suggest the notion of companion pedagogy to describe this way of inquiring companionably side-by-side in dialogue, exploring our own and other women's creative histories and stories. Companion pedagogy incites self and co-directed explorations, learning and healing of selves, histories and stories. Our companion pedagogy is a feminine, relational, maternal movement of co-inquiry-based learning. This supports us to nurture changes in ourselves and the current social climate-in an echo of timing that reflects the prior concerns of the May 1968 era in France for more open, equitable, compassionate societies. Companion pedagogy teaches us that to sustain the creative, healing learning and teaching we seek, we need each other-we are not alone. We need to develop communities of practice through gifting relations, which for us are rooted in that sense of Mother writ large.

Residing in France, we also appreciated that language comprehension is a form of discourse in which we take in and create meaning in relationships, culture and life. By "language", we include modalities of visual, aesthetic, embodied, geographic, linguistic, rational and also arational links (Bickel, 2020) between the human and more-than-human worlds. Barbara specifically explored morethan-human life expressions during this residency, through her interactions with the natural world of trees, soil and place itself. Meditating and studying across languages, cultures and the land is a form of educational inquiry and "worldliness" (Pinar, 2009), honouring all worlds, including intangible

\footnotetext{
${ }^{6}$ We were lucky to view the exhibition of Italian artist Carol Rama's lifetime oeuvre at the Musée D'Art Moderne, which ran from April 3-July 12, 2015. Rama was 97 years old at the time of the exhibition, and passed away that same year. Her inspiring provocative artwork, with experimental uses of material and imagery, spanned eight decades. Rama's artwork ranges from her early female-centred, erotic life force depicting drawings, watercolours and paintings, to the creation of assemblages and sculptures with textiles and found materials.
} 
places of soul and spirit.

As companion pedagogues, we herein weave excerpts from our life writing with quotes from Hélène Cixous' text, Coming to Writing, a 1991-translated text from the original French of 1977, La Venue à l'écriture. Cixous' French title is a word-play on "La Venue", meaning coming, as in its English translation, yet also referring to a road/avenue, and sounding like Venue - the Goddess Venus. So that coming to writing is on a road and pathway, while hinting at the lost feminine, and love itself. Much is lost in translation with Cixous, but we can still follow her text in English, which playfully yet seriously explores the yearning, effort and need to write. This is writing from and with the body and life, unearthing the missing or repressed feminine via storied views of Cixous' own avenues to textual life. As she notes: "Life becomes text, starting out from my body. I am already text. History, love, violence, time, work, desire inscribe my body" (1977/1991, p. 52).

Our own writing herein will soon shift from the tone of this scholarly narrative, to story-sharing our experiences in first-person voices. We draw from our journal and blog writing for the life writing that follows. We braid our differing but connected story threads through the arts-based practice of literary métissage. Métissage is based upon life writing inquiry in the notion of "weaving" texts and voices of more than one author into a single creative non-fiction braid (Hasebe-Ludt et al., 2009). Our weaving offers the reader a storied back-and-forth dialogue between our voices, as we share themes and locales of our Paris residency.

We thus offer you moments and insights from our studio, inviting you, dear reader, to wander with us through Paris. Sharing life writing in this way amounts to the findings of our research, which are not meant to foreclose or submit conclusions for this inquiry. Instead, we aim to open and draw from experience as text, in hopes of touching or sparking your thoughts and feelings towards your own inquiries. In sharing this tapestry of stories through life writing, we hope to inspire in others the gift of space-making in restorative studio residencies for healing education, and for creative collaborations with your own companion pedagogues. 


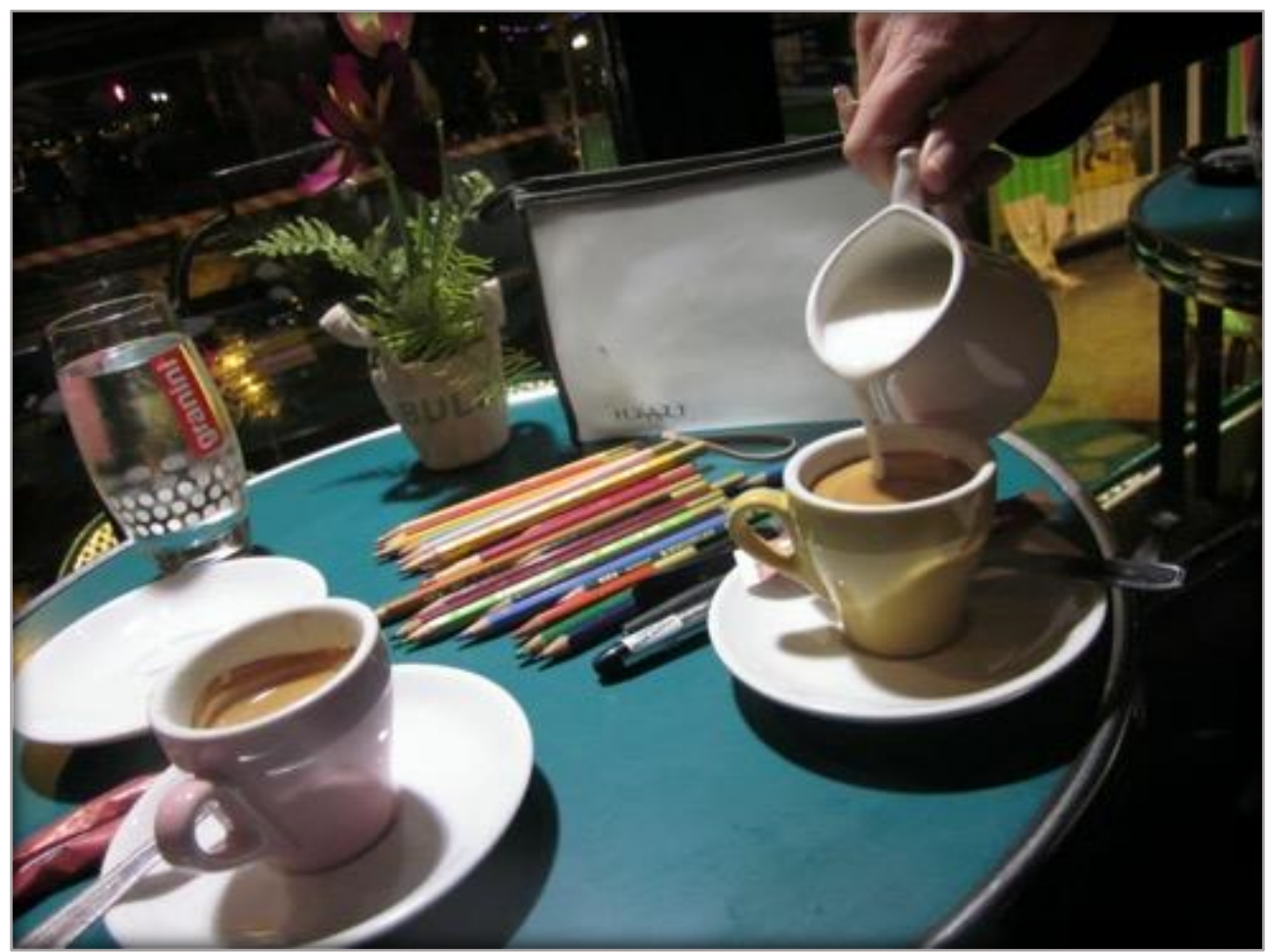

Café noisette, ready to draw, near Notre Dame Cathedral, Paris. Photo by Nané.

\section{Writing Life and Art: A Métissage of Paris Stories}

\section{Barbara}

This was a return for me to Paris after a 32-year absence. My first visit to Paris was as a responsibility-free young woman on a nomadic bicycle tour of Europe. I have an ingrained memory of precariously riding my saddlebag-laden Raleigh bicycle on the cobblestone roundabout of the Place Charles de Gaule amidst multiple lanes of cars while simultaneously awestruck by the Arc de Triomphe I was circling about. Joining Nané in this life writing artist residency became a pathway that intersected with my prior month of walking many miles while on sabbatical travels in England, Turkey, Italy and Germany. Our side-by-side steps were infused with freshly lived arts- and placebased inquiries and learning.

My writing herein focuses on a set of poems that emerged from an awake-dreaming, trancebased inquiry practice I undertook in the park surrounding the Cité Universitaire, a gathering and living place for international students and scholars who study in Paris, where I stayed with Nané for our residency. I use trance journeying as a visualization inquiry practice to inform my art making (Bickel, 2020, 2014). Through trance, I consciously step out of normal time to enter a transpersonal dream-time journey. This particular journey took me into a non-human form of the element of carbon. In my dream-state, I floated high into the air, gaining a moving aerial perspective of the places I had been, and would travel, after my departure from Paris. This trance journey integrated the 
international learning experiences of my sabbatical, emotionally preparing me for my reluctant return to the United States.

I entered the trance in the garden at the Cité. The trance became a prayer for compassion among all beings and for international peace, based upon my experiences of connecting with international students, scholars and their lives. I chose to sit on the earth at the base of a beautiful double-trunked tree, which reminded me of Nané and myself, working together as companion pedagogues. I heard conversations in many languages as people walked the garden pathways nearby. With the tree as my sacred starting point, I began my trance journey, which I spoke out loud and audio recorded as the dream-like story unfolded. After transcribing, I transposed this trancedream journey into poetic form, noting with my usual awe how scientific research reinforces the ecological elements of my trance experience, in what some call "geopoetry" (Hess, 1962).

\section{Timeless Travel: A Carbon Prayer}

Sitting on the earth

in the jardin of the Paris Cité Universitaire

I lean into the double trunk

tree resting

after weeks of walking

cobbled stones and cement pathways

in large European cities

I welcome this

verdant earth

Becoming one with the tree

mobile watery sap

uploads into my back

flowing upward

then outward diverging

into two trunks

Cellular nourishment

travels through branches

transfers into leaves

fluid communications

between split trunk

conducting signals

transporting airborne messages

to the blue sky 
Warmed by the sun

I float up as carbon

sequestered carbon

now airborne above the park

cathedral of angels

comes into view

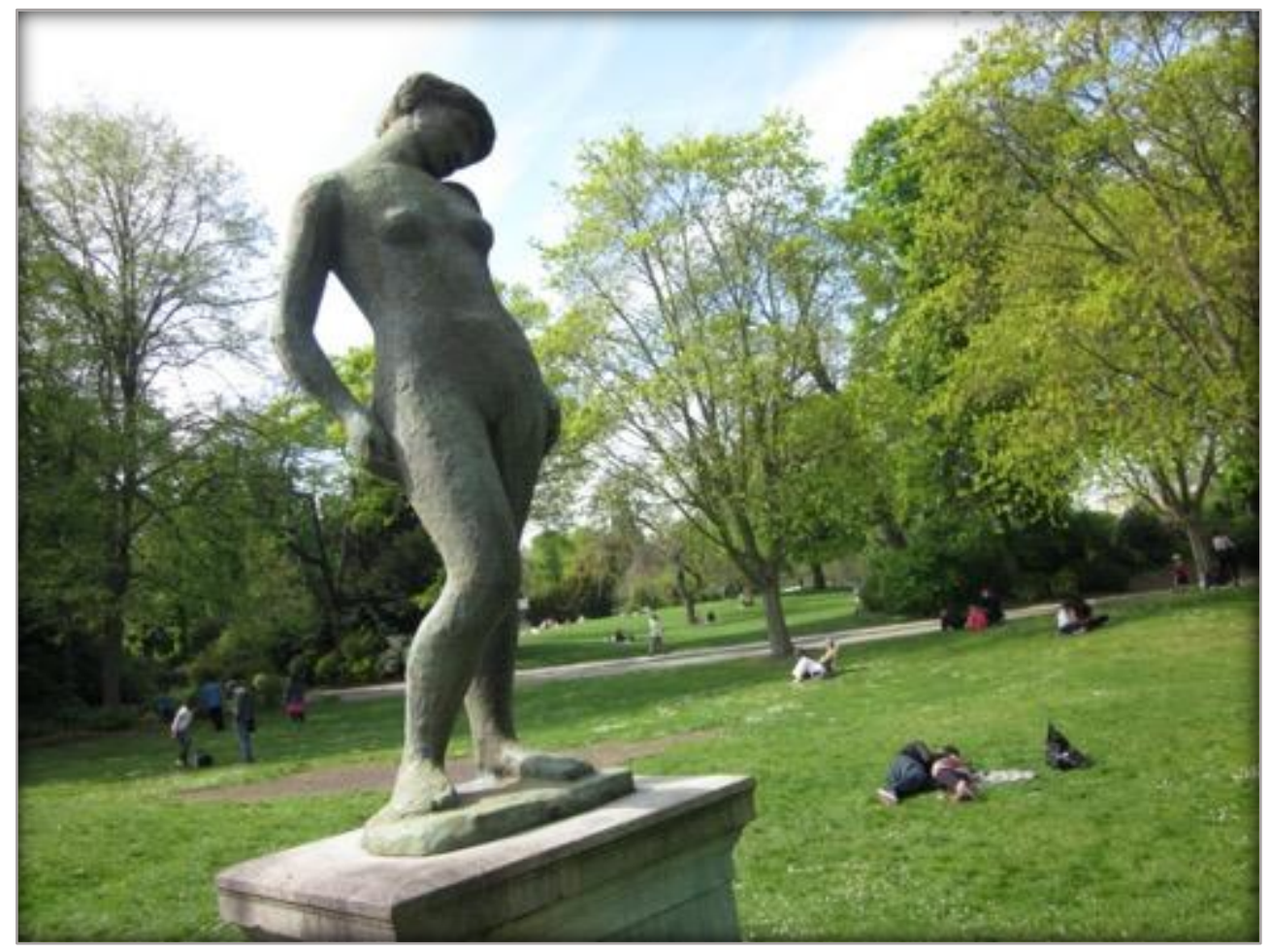

Parc Montsouris, across from Cité U, Paris. Photo by Nané.

Nané

Maybe I have written to see, to have what I never would have had. (Cixous, 1977/1991, p. 4)

I sometimes feel overwhelmed, doing my research in Paris. It is wonderful, yes, but I feel how Paris takes over in the sense of the pre-eminence of this place as both real and imagined. Paris is often idealized, based in the many things she offers as a European capital of culture, with her art, museums, architecture, food, and artful living. This is further exemplified in her multiple cafés that I love to stop, visit and dream in-especially with my low energy, I remind myself there is always somewhere I can stop to sit as needed. My work and being here feels affected by this real and imagined Paris, by how I am a stranger to this place bringing myself towards new life and inquiry. It is as a dream, a dream come true.

While in the very real, yet imaginary Paris, I feel a strange unwieldy yearning. Yearning tugs on my dreams, as if I am being called by Paris-artists of old. I am both deeply fulfilled yet emptied all at once, as I do the creative work of rebirthing myself. Each day, I reach beyond myself in language, 
place and understanding of Cixous' life writing and "Cixousian" thought, as history and love trail me everywhere. This is especially so in the absence of my husband and daughters, as I am working far from my home in Vancouver, Canada. I feel twinned pleasure and pain in their absence-there is space to restore myself individually, yet with loss of their co-presence. Their lives gift me my own life, through reciprocal relations of care and love. I navigate my work in the complexity of Cixous' texts in French and France by threading myself through the needle-eye of being in Paris as a migrant of choice. Mine is a chosen displacement from family and homeland. Yet, while I am here, in this year of 2015, many others are arriving into Europe, in desperate need of shelter and new life away from the ravages of war.

Through migrations, new and old, I feel how Paris is an archive-an archive of the West in its art and culture, and also its histories of war. A lineage of archive is alive in all the Paris people, descendants of other times, yet full of contemporary life, in the streets and cafés, or hidden in their apartment homes, in this busy city of art, love, history and modernity. Of great impact, in this year I am researching, are terrorist attacks that occur in February and November of 2015. These incidents bookend my travels, and affect Parisians with uncertainty and new fear. I walk the streets with others, in knowledge of the February attack, witness to an increased police presence. Yet life goes on in all the ways that Paris lives herself through her open cafés and amiable public life. I observe from February through May of 2015 that there is a new guard stationed at the entrance of the Cité where I live. I see that he is gone by my October visit; we do not know the events of Friday, November 13, 2015 , that are yet to come.

Paris is an ancient meeting place on the river Seine; Paris is the Lady, a Goddess, Notre Dame, a Mother holding and leading me onwards towards new phases in my own life. In simplicity, and due to my recent health ailments and fatigue, my basic practice is visiting the Cathedral of Notre Dame. ${ }^{7}$ As a women's spirituality scholar, I am critical of the patriarchal dogma and misogyny of Church and society. I live and create towards new visions of women's spiritual leadership and experience that value diverse embodiments of women. I honour a Goddess-sized divine feminine/female presence and power in all the birthing, maternal, regenerative forces of life (Jordan, 2011, 2013). In this almost thousand-year-old Cathedral, I light candles at the Marian altars. Standing before images of Mary, who I view like a Mother Goddess, I feel bathed in the love of her gifting maternal presence. I devote healing prayers to Mary as Mother of the Earth and the people. In devotion, I am held by her, and able to hold more of my own suffering and love. I feel some relief and even contentment.

Barbara and I spend our first evening together in Paris at Notre Dame, coming out of the rain. I light candles and think of others who are not here with us, our colleagues, friends, family and communities, those others far away. This evening, we have stumbled into a concert of the Grand Organ, which fills the vaulted ceilings of this huge, cave-like sanctuary with bold and sinister choral

\footnotetext{
${ }^{7}$ In the summer of 2019, people watched in horror as a huge fire erupted on the roof of Notre Dame Cathedral during renovations, destroying the roof and much of the Cathedral's interiors, while releasing tons of toxic lead-filled smoke and residues into the local neighbourhood during the blaze. At this time, Notre Dame is completely closed and awaiting multi-million dollar repairs.
} 
tones. This music feeds my sense of how suffering and love coincide as twinned energies in my yearning and dreaming. I feel happy to sit beside my friend in this grand space, while Gothic tones boom from crescendo to decrescendo, as if the hunchback of Notre Dame is coming to life. We listen, feel and absorb the sounds.

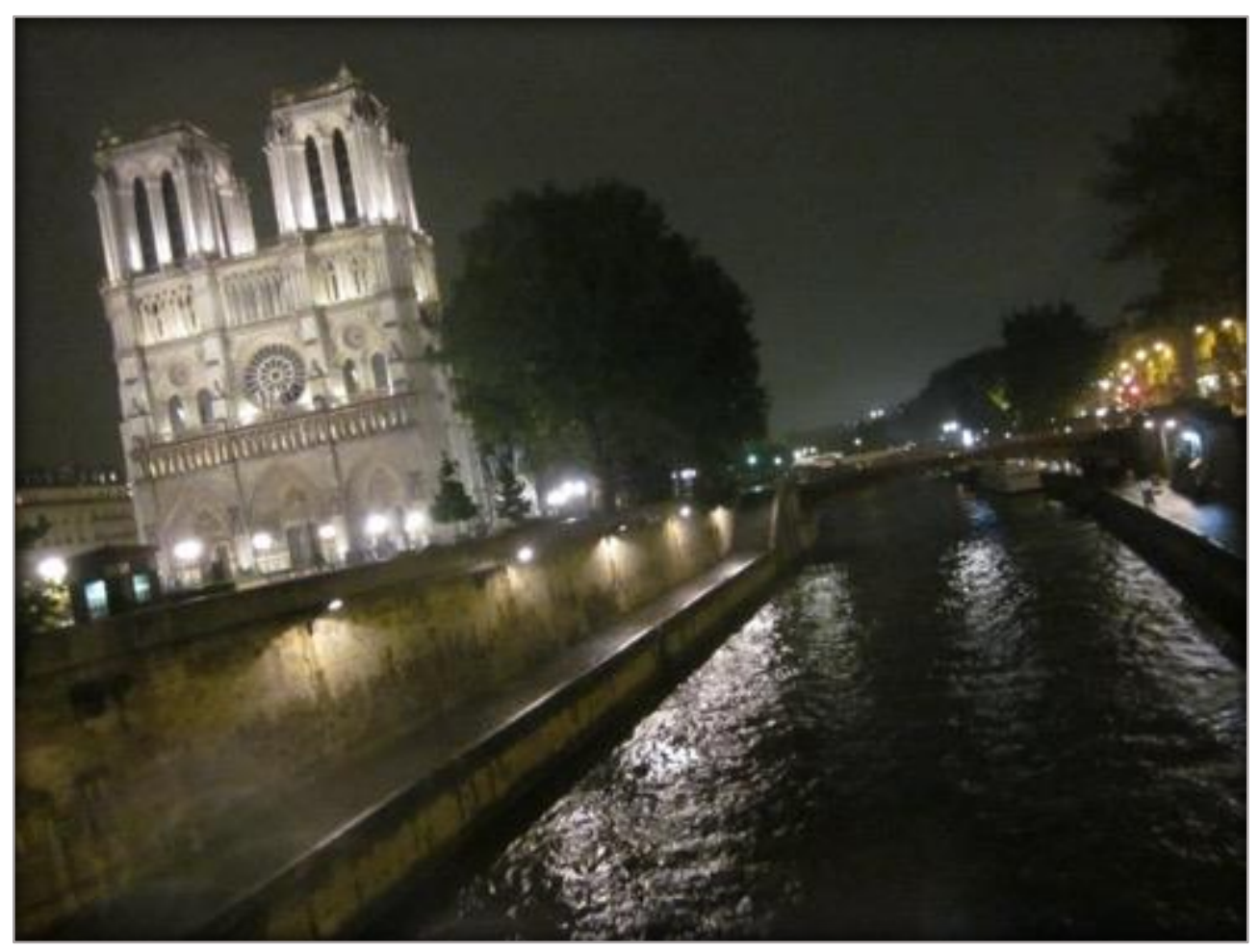

Notre Dame on the Seine, rainy May evening, Paris. Photo by Nané.

\section{Barbara}

Drifting above Paris I see

cars in motion

tracing square and circular lines

tightly scheduled metro

and trolleys in their tracks

green spaces breathing

people walking

Flowing above the river Seine I hear

Notre Dame music

gently wafting up

tensile carbon steel organ wire

transmitting particles

ionic acoustic waves

hmmm hmmmm 
singing airwaves

singing birds

singing people

a multitude of healing sounds

fueling quality of air

assemblage of positive ions

carbon particles buoyant

Following the river path

floating beyond the city

Seine meeting Rhine

no border

no division

between Germany and France

waters flow free

Contemplating Berlin

holocaust memorials

congested roadways

trauma traveling through

rendered acoustic waves

fluent blending of

human voices

German French Turkish English

efficacious songs

sending teachings skyward

Following waterways south

to Rome

Tevere river music

composes voices

in the sky as I hover

above the old city

Gliding over the Vatican

and nearby cathedrals

I gaze into Castle Santa Angelo

watch people labyrinth walking

cobbled stone passageways

of the ancient city

labyrinth paths

with piazza centers 
Nané

For the flesh is a book ...; the flesh is writing. (Cixous, 1977/1991, p. 24)

For daily living in Paris, we are well housed at the Cité Universitaire where I live when working in Paris. Our accommodation is studio-like, with a sleeping loft, a living area and kitchenette.

Students and researchers from around the world live at the Cité, a world-community for study in the Paris university system, built by the French after WWI to promote peace and understanding through international studies. I love staying here and being part of this cosmopolitan community of scholars, living in networks of beautiful buildings surrounded by rich green parklands that I often wander in. This supports my sensual restoration and embodied healing, and now Barbara joins me in these healing walks.

Barbara and I quickly intuit how to spend our time, framing our week together as companion pedagogues on a studio respite from our regular routines, in this ancient European city of art. We create a morning posture practice, based on 13 poses of the ancient, primal Mother "MA", as described in the research of feminist art historian Annine van der Meer (2011). We recently met Annine at a conference, and gleaned this creative embodied practice from her text-based, analytical research on "global Venus art". 8 Our MA poses draw from the evolution of the female image in the last 40,000 years, through in a series of postures held by female icons across the ages, from Paleoand Neo-lithic eras into pre-historical and historical times of Goddess myth and symbol. The poses embody the regenerative wisdom of the female life cycle. They represent forms of potent Mother Goddesses, forces of MA in her creative capacity to gestate new life from within-an echo of our own hopes for this residency to regenerate ourselves, birthing life anew. We discover how the MA poses become portals for embodied knowing and meaning, for listening more deeply to our bodies through cellular whisperings and maternal ancestral wisdom (Bickel et al., 2019). We follow this practice with free-writing, sharing our insights, and remembering our nightly dreams, inspired by Cixous' own attention to dreams. Cixous (2008) writes: "In my work, my luck is to have a writing partner who is none other than the dream. ... I begin to dream in such a way that dream and text endlessly exchange" (p. 55).

During our days, we take walks and visit art galleries, cathedrals and historic sites. We follow up our outings with spontaneous colour pencil drawings in Barbara's small notebook, sitting side by side at one of Paris' ubiquitous neighbourhood cafés, enjoying the sensual life of the body that Paris attends to so well. Barbara does not speak French and I begin to appreciate my ability to converse

\footnotetext{
${ }^{8}$ Nané and Barbara met Annine van der Meer in Rome, Italy, in April, 2015, at the combined international conferences of The Mother Initiative for Research and Community Involvement (MIRCI, led by professor Andrea O'Reilly of York University of Canada), and The Maternal Roots of the Gift Economy, (led by philosopher Genevieve Vaughan of Italy). Nané and Barbara are long-time members of MIRCI, and each contribute to the fields of motherhood studies and the gift economy. Attending this conference together while co-presenting a Gestare-based workshop, contributed to the unfolding of our Paris studio residency. We drew from nourishing, mother-centred threads of experiencing gifting networks of mother-scholars, and meeting and talking with Annine in person about her book. In typical Gestare fashion of liberating spontaneous insight, we quickly intuited, gleaned and acted upon the MA poses as a practice.
} 
and understand French. I am becoming accustomed to the language, yet struggle with understanding all, more and better.

We also attend one of Hélène Cixous' monthly Saturday seminars located at the Cité. Cixous' seminars have continued beyond her retirement from professing at Paris 8 and are attended by a mix of scholars, students and community members, many with hair as white as her own. Listening to Cixous, I can relax into the French language through the flow of her carefully chosen words and ideas. She sits at a desk at the fore of a large lecture room, backed by windows that look out onto green spaces of the Cité grounds that visually support her audience's trance state while listening to her soft speaking. Cixous deftly navigates her chosen texts as if stitching textured quilts of thoughtsin-words.

In the evenings, Barbara and I work on individual life writing blogs in English, tracking our experiences and emergent ideas. We read Cixous' translated writings aloud to each other and dialogue on their musings and meaning. We also exchange relaxing back massages prior to going to sleep, deciding that releasing stress through healing touch is important for this residency time of embodied renewal.

In it all, I am very far from home and the needs of my family. I miss my husband and two daughters dramatically, in ways I couldn't have anticipated. Yet I contiguously feel at home in this space, sensing gifts of time and place. I'm being given a view of my life through companion inquiry, as Barbara and I nurture and share in the value of this spaciousness. Walking the Cite grounds, travelling through Paris by Métro, strolling along the Seine, visiting art galleries and cathedrals, attending Cixous' seminars and reading her texts-these all become the embodied practices and lived journey metaphor we need. Paris holds us in our yearning; we are travelers and researchers of body, mind and spirit. 


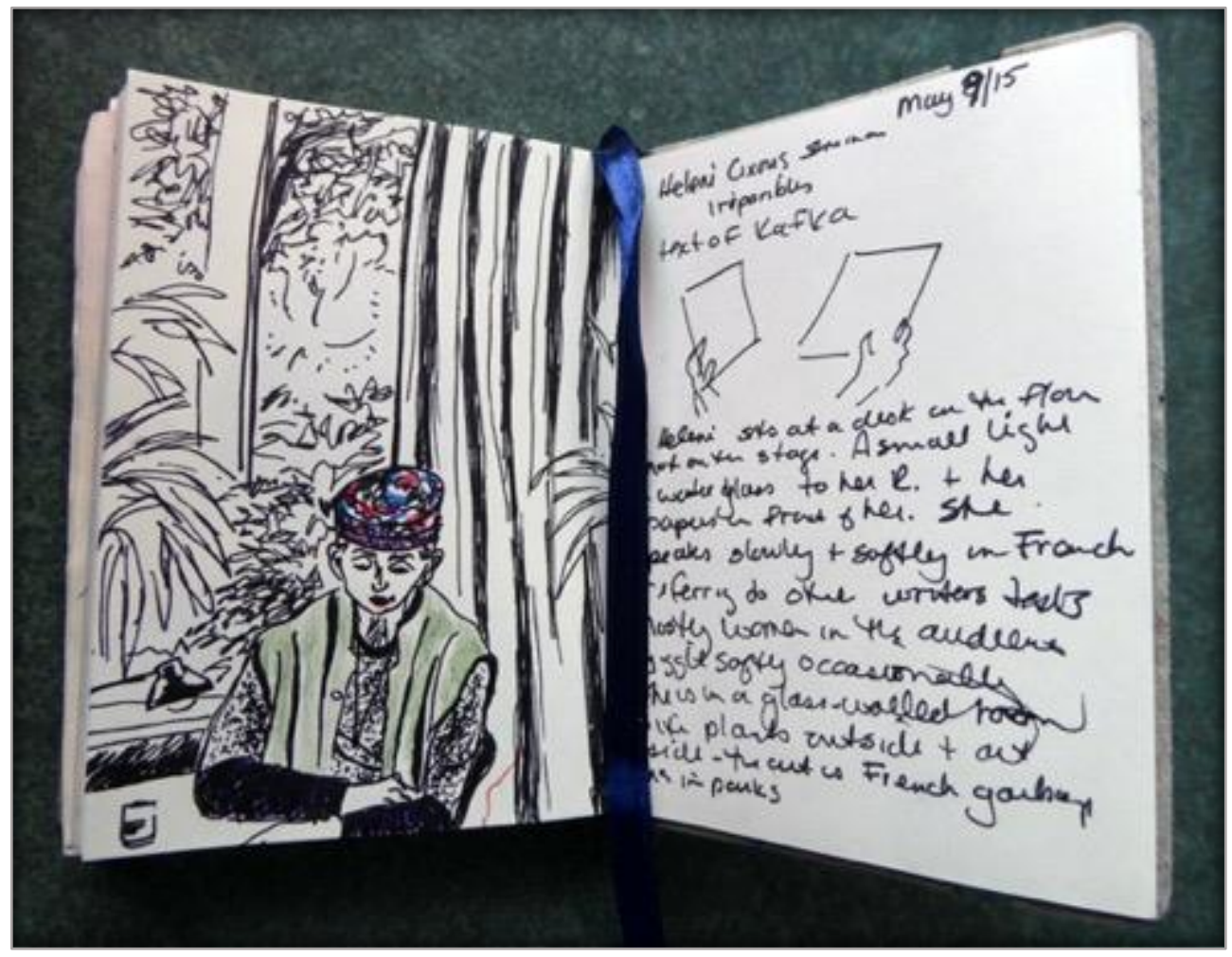

Hélène Cixous giving her monthly Saturday seminar, Maison Heinrich Heine, Paris. Drawing and photo by Barbara.

\section{Barbara}

She is hers, and if she wishes... she can take and give of herself to herself. It was in watching them giving birth that I learned to love women, to sense and desire the power and resources of femininity; to feel astonishment that such immensity can be reabsorbed, covered up, in the ordinary. (Cixous, 1977/1991, p. 31)

Sharing the MA pose practice with Nané each morning in Paris, combined with seeing an exhibition of Carol Rama's art at the Musée d'Art Moderne, foregrounds the confused status of erotic life force energy emerging from women's bodies in art and culture. Our daily MA pose practice, followed by writing, taps into the wisdom of the body, and generates new understandings of how we engage with the world at a more subtle level. This MA context is often repressed, yet appropriated for consumption in the male-centred, phallo-centric context in which art and culture has been historically viewed. American dance educator Vajra Ma (2015) states that although feminism has developed "crucial cognitive understandings to dismantle patriarchal concepts" (p. 233), women "still need to cultivate full embodiment at the subtle, neural level. ... To restore their wombs and subtle bodies ... the next wave of feminism must take women fully into the body" (p. 233).

Carol Rama's 1945 exhibition of her early erotic vulva- and penis-filled artwork in Turin, Italy (her home town) was banned as obscene. According to notes at the exhibition from curator Beatriz Presiado, Carol Rama was a contemporary of Picasso, Duchamp, Luis Brunel, Man Ray, Jean Dubuffet, 
Orson Wells, Warhol, Sanguinetti, la Ciccoline and Jeff Koons-but she was an invisible contemporary, not found in art history books. After being censored, Rama stopped creating her sensuous female imagery, with its wild plant-like hair, snakes emerging from vulvas, and male partners with erections, until the 1980s. This makes me sad and angry simultaneously.

Rama's life's work is now being written about, studied and seen (Vallora, 2008). The retrospective exhibition we saw was powerful in that it traces her journey through art and life. Rama died not long after we viewed this exhibition, close to 100 years old. Over the years she worked with watercolors, textiles, rubber from bike tires, and found objects such as dolls' eyes. Although this was aesthetically strong work, Nané and I were most impacted by Rama's early erotic images, which restore the power of the feminine, and the language of MA in culture and art. Because Nané and I were practicing the MA poses and immersed in research on female iconography, we drew a parallel between Rama's work and the historical Sheela-na-gigs or Vulva Ladies, which appeared in the Middle Ages, and were found over Church doorways in Ireland and Great Britain. Also, the Lady in a birthing position from the Lion Pillar building in Gobekli Tepe from the Neolithic period of Turkey shows a birthing woman squatting, with perhaps an umbilical cord or blood emerging from her vulva (van der Meer, 2011, p. 122) that resembles Rama's snake-women. The snake is a symbol connected to women across the ages, not only biblically but predating such. Snakes are closely connected to the power of the earth and Mother Earth, in coming in and out of the ground, and remind us of the regenerative power of life as they shed their skins to be born anew-connected as this is with sacred cycles of menstruation, fertility and birth.

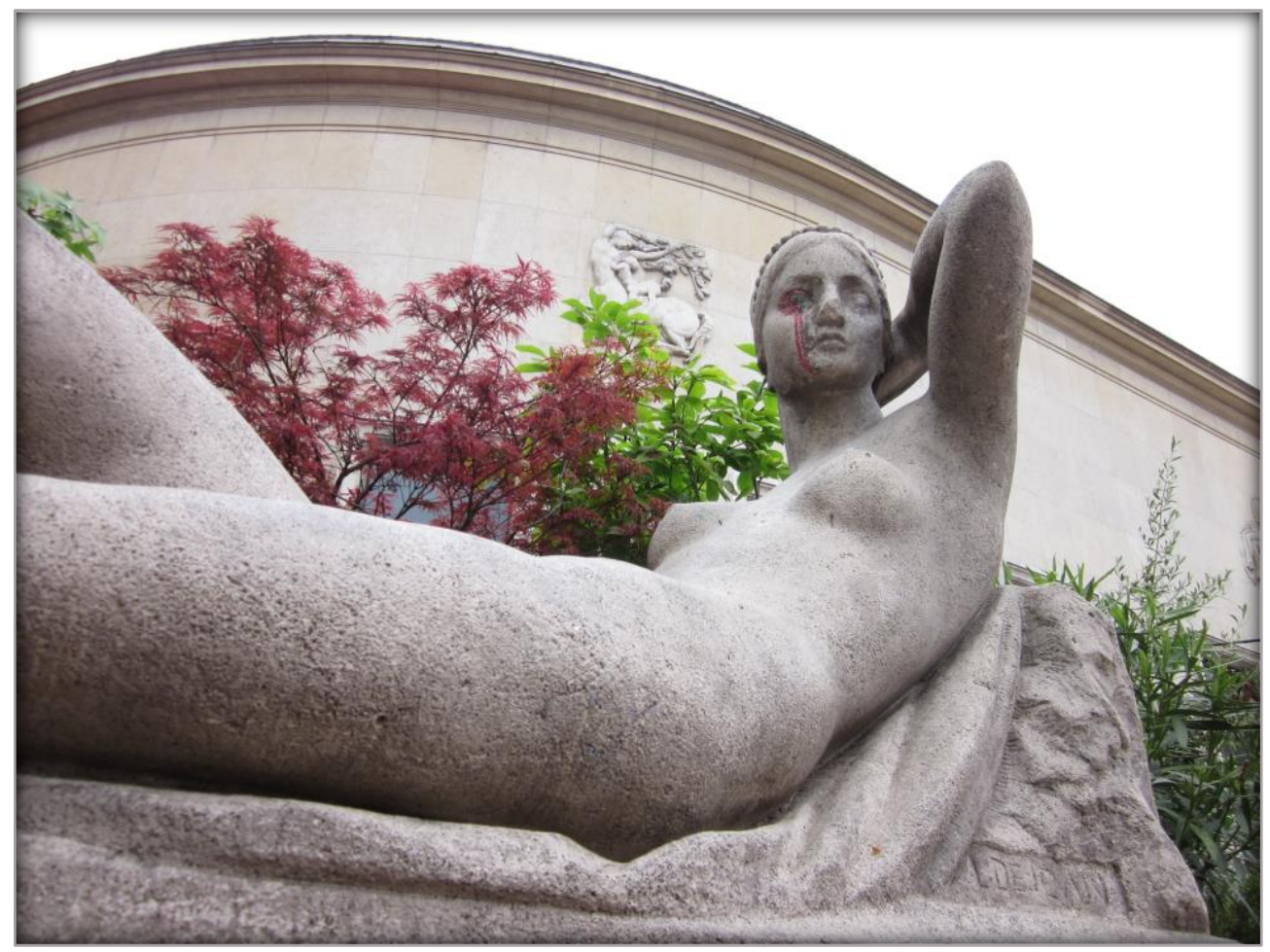

In the Plaza near the Musée d'Art Moderne, Paris. Photo by Nané. 
Nané

Worldwide my consciousness, worldwide my body. What happens outside, happens inside. I myself am the earth. (Cixous, 1977/1991, p. 47)

The body is always a substance for inscription. (Cixous, 1977/1991, p. 26)

Entering the snake-like Paris Métro, we trace our way through underground labyrinths of tunnels. Walking underground, these vein- or root-like interconnections are filled with people in movement. Like snakes, we wind our various ways into the earth, waiting on platforms to ride and bump along at high speeds under the city of Paris in loud, slinking train cars. Emerging again into daylight, Barbara and I arrive, after an hour's ride, at the University of Paris 8. We are about to hear an invited speaker, Dr. Jacqueline Rose. She will give a talk in professor Anne Berger's lecture series on the understudied topic, in France and elsewhere, of "Maternités" (Motherhood), at the Centre for Women's and Gender Studies, le Centre d'études feminine. The Paris 8 campus is located in St. Denis, a working class neighborhood on the far north end of Paris. This is a vibrant campus of students from diverse backgrounds and ethnicities. The French education system strives to keep low-cost tuition for student access, yet limitations of funding appear in how many classrooms need updates or repairs.

French colleagues comment that women's and gender studies has a long way to go in France, but that may be true in North America, too. Though we think of this as an established discipline, it is often sidelined as a field of study. Yet such studies are vital, and ever transforming, by developing ideas in response to sex and gender justice and needed social change. Like the re-conceptualist and Aokian (a.k.a. Ted Aoki) curriculum scholars and arts-based folk with whom I studied life writing in Canada, there is a relational stream of professors here in the Centre. These people were taught or mentored by Hélène Cixous, so that the Cixousian gift of inquiry, response and response-ability is passed down the line.

My longtime involvement in both women's spirituality and the field of arts education is highlighted by nourishing time spent with mentors in innovative streams of thought and practice. These people truly care about, and midwife, their students. Life-giving teachings are passed along from teacher to student, in a birth-like wayfinding, so that we can respond to the needs of our lives and times with enhanced gifting capacities-in a healing definition of education. I feel the Cixousian gift this way at Paris 8 , as people attend closely, and with care, to each other's ideas and creative methods. This is the thread that carries me along during my research, where the careful work of thinking and being that is "études féminines" is held and valued. Cixous' thoughtful choice of the word feminine (the feminine), rather than femmes (women) for the centre, was meant-in the context of the 1970s - to denote and include women's studies, but also to be more-than the category of "women" themselves. Feminine opens what has been repressed or previously unknown in philosophy, literature, culture and religion-and the looping, generational antecedent of all these studies as education. If ever there was a field of study that denoted human regeneration and 
evolution, in ongoing human births and inevitable mortality, it is certainly the field of education itself-where gifts of knowledge and practice are handed across the generations.

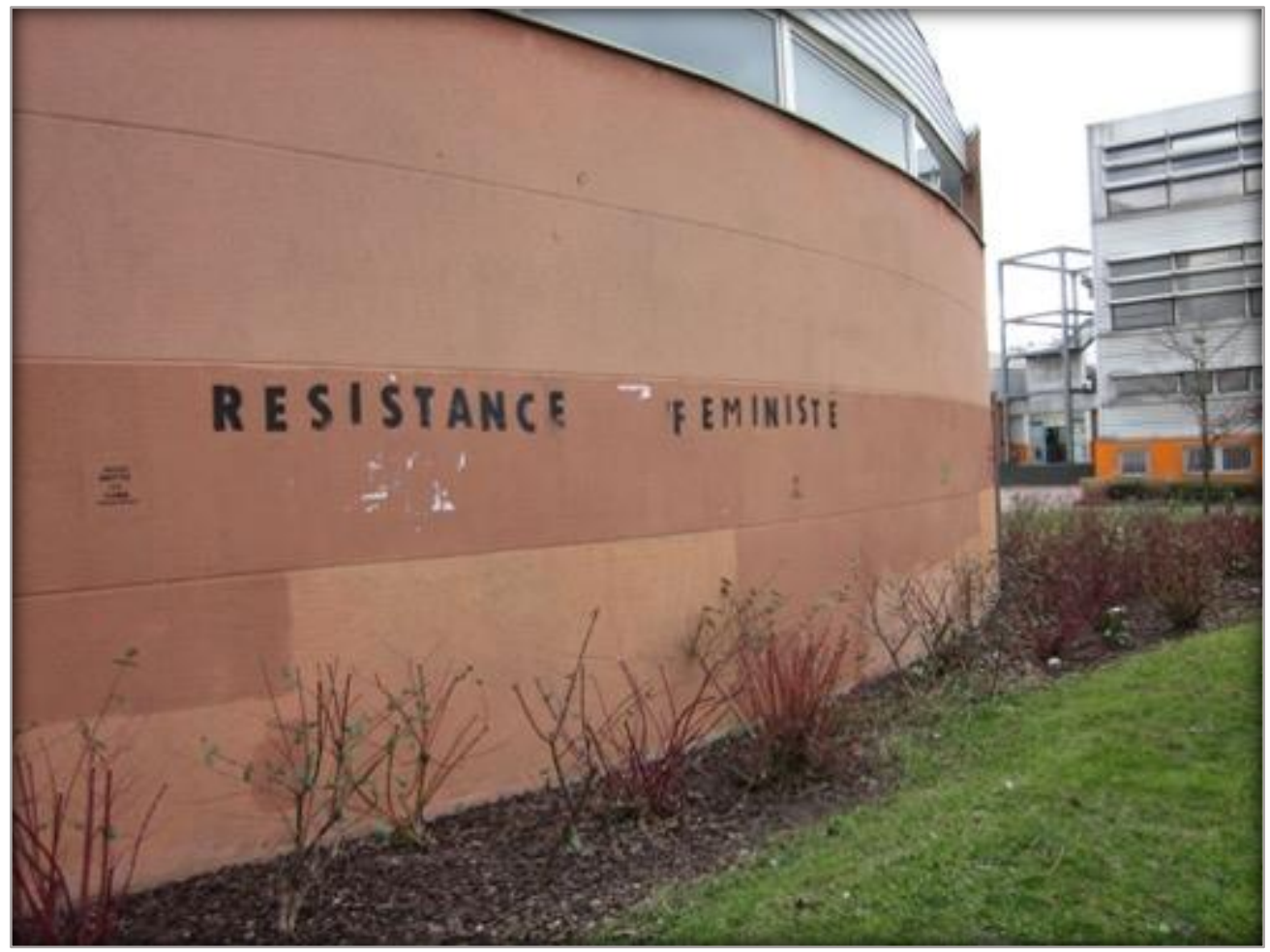

Graffiti art of the University of Paris 8, Paris. Photo by Nané.

\section{Barbara}

Crossing cold waters of the Atlantic

to Canada

where my feet have walked most

double trunk trees entwining

political change of wind

in the province of Alberta

collective trunks interweaving

people awakening

to trauma-creating divisions

Indigenous and European

African and European

May living energies from this double trunk tree

spread through the United States

up down across

connect to the lost carbon of the double trunk tree 
in the state of Illinois

in Carbondale

in my backyard

felled double trunk tree absent

now a mini forest

diversity flourishing

sharing particles

as remedy rather than toxins

nourishing rather than marginalizing

Jet stream wind gusts catch me

carry me back over

the Atlantic Ocean

to the green earth

the double trunk tree

holding me

this international campus

holding diversity of languages

colours ideas religions

Globalized carbon downloads into my being

full body weight leaning into double trunk

birds singing

merci merci, tesekkurler, tesekkuler,

thank you, thank you, dankeschon, dankeschon

and all words for thank you I do not know

May spaces of learning

expand and grow

expand and grow

as we turn forward

turn forward from wars and sorrow to

the healing branches of

peace and compassion with

restoration of our double trunkedness 


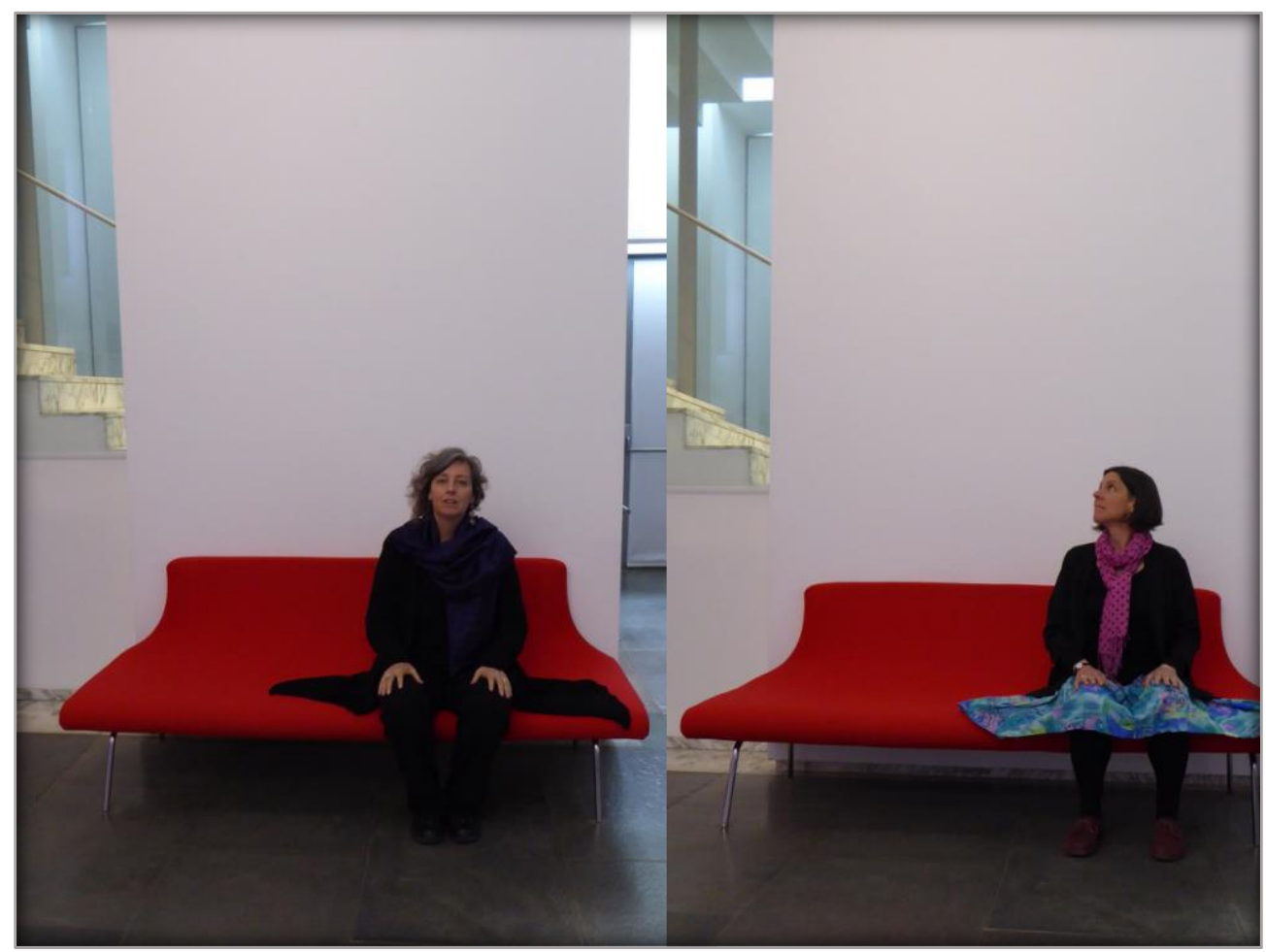

The author-artists at Gallerie Jeu de Paume, Paris. Photo by Barbara \& Nané.

\section{Closing Notes}

My flesh signs the book. (Cixous, 1977/1991, p. 53)

And so we end our Paris studio residency journey, holding the "restoration of our double trunkedness" as companion pedagogues. We share the finding of selves as companion pedagogues as a heart-centred pedagogical gift that we hope will influence, even in small ways, the next stage of educational and social evolution to be a healing one, growing from love itself. Like the University of Paris 8 , this form of teaching and learning goes beyond fixed notions of curriculum and neo-liberal imperatives, to restore the unique personhood of students and teachers, and to support wellbeing for all. Healing education acknowledges individual and collective impacts of traumas in lived realties of war, migration, colonization, environmental devastation and interpersonal trauma. Healing education encourages resiliency through our relational ability to share restorative practices and heal with each other, to birth our-selves anew like snakes from the earth of our storied lives.

This way of learning and teaching is based on a gifting economy, wherein we collectively create spaces of attention and care for each other, restoring hidden, lost and forgotten gifts of creativity as educators, students and researchers. Engaging with the arts and writing are reparative practices in this regard, through art viewing and making, life writing and reading, and sharing embodied practices with others. Though Paris was the locale for our studio residency, as Nané had the opportunity to live there, residencies can be created anywhere and anytime that two or more 
educators want to gather and create a focused time away, time out or "time in", attending to the flow of education as a fluid duet of inner and outer work. Because if ever there was a field of study that denotes human regeneration, healing and evolution in our ongoing births and inevitable mortality, it is certainly the field of education itself, where gifts of knowledge and practice are handed across the generations. How and why we do this matters.

We thus invite you, dear reader, to create studio residencies of your own, to collaborate with others, to create together in living, wayfinding, art-making, and in writing the stories of your lives. May you find and re-find your-selves, pay attention to and value each other and the stories that matter to you in this time. Based on our residency, we close with nourishing steps to take for creating studio residencies.

1. Create a basic routine each day early on. It is important to hold a container for rest, reflection, walking, visiting places, art making, body-based practices, reflective life writing or other meaning-making activities.

2. Draw from the gifts of the local environment as a "classroom". Pay attention to the place you are in to direct activities; this attunes awareness and connections between self, other and place.

3. Attune to, and draw from, the needs of those present. If people are depleted, create time for mindful restoration; consciously practice following others rather than leading, or vice versa.

4. Invite and engage with the gifts of those present. This may include co-leading activities together, offering skills or ideas, or experimenting playfully with new practices.

5. Allow quiet space, alone or in the presence of each other, to write or sketch, documenting emergent themes from each day. The beneficial use of restful, reflective creative practices leads to novel insights and strengthens pathways of inquiry, and these become directions for new or needed work.

6. Take time to check in with yourself and with each other at the start of the residency, and continue to give time to attending to your self and the other each day. Sharing "where you are at" assists staying attuned to the expectations and needs of all; it is best to work with "what is" rather than what one wishes would be. Honour yourself and your needs as creative fodder for the studio.

7. Take risks. If a seemingly strange idea pops up, be open to considering it.

8. After the residency is over, follow up with each other on the practices, ideas and insights that emerged. Do you want to explore them further together? Or teach and share them with others? Take time to continue to life-write individually and together about the residency, as we learn through further inquiry into our stories. 


\section{Epilogue: Our Flesh Signs the Book}

As educators, in this new time of 2021, we continue to follow feminist/feminine threads that honour and gestate a more nurturing, mothering humanity to come forward for gifting a healing education. Especially heightened now are "essential" services of mothering and nurturing in this pandemic time. We understand our lives and the field of education creatively, organically-as lifegiving, life-gifting, life-writing relations. As we write this essay towards publication, we note that neither of us are currently employed in academia. We both remain active in our creative scholarly work and gifting service to the field of arts and education. Nané is currently working in Indigenous community and family services, and continues her creative birth-based research, writing and art projects. Barbara has returned full time to her art and writing practices, and teaching art, now completely through the gift economy.

Thus, almost six years after this residency, we find ourselves living grassroots educational, scholarly and studio life practices of art-, family-, community-based healing and developmentgifting artful practices of care in community with others. Additionally, we have both published scholarly works since that time, which draw from our combined themes of the gift economy, feminist mothering, birth-based philosophies, restorative, embodied educational practices and trance-based inquiry. This includes Barbara's 2020 book, Art, Ritual and Trance Inquiry: Arational Learning in an Irrational World, and Nané's 2017 edited anthology, Placenta Wit: Mother Stories, Rituals, and Research. We feel that directly and indirectly, these transformative texts were made possible from our ongoing commitments to the relational, restorative arts-based educational practices we cocreated and experienced during our Paris studio residency of 2015.

Into this educational and scholarly trajectory, we continue to draw nourishment for restoration and resilience from the ancient MA poses with the Gestare Art Collective. MA poses have grown from our Paris studio residency, and have been shared with many other people across North America as an embodied inquiry practice (Bickel et al., 2019). We continue to consciously attend to women's artistic practices, and to honour female embodiment as a sacred site of knowing and being that requires soulful work, nourishment, rest, relationship and care in community with others. We value and create art from our inter-connections with the natural world, listening to the trees, to the subtle and spiritual facets of our lives on Mother Earth. To sustain this creative, healing education, we behold the beauty and love in each other, in our families, friends, colleagues, students and communities, in the many life-worlds around us-we are not alone.

\section{References}

Bickel, B. (2014). Led by spirit: A spiritual feminist arts-based inquiry. In S. Nicholson \& V. Fisher (Eds.), Integral voices on sex, gender and sexuality: Critical inquires (pp. 209-320). State University of New York Press.

Bickel, B. (2020). Art, ritual, and trance Inquiry: Arational learning in an irrational world. Palgrave Pivot. 
Bickel, B., Jordan, N., McConachy, M., Rose, I., \& Griffith, C. L. (2019). MA poses: A new material feminist art practice. In P. Sameshima, B. White, \& A. Sinner (Eds.), Ma: Materiality in teaching and learning. Peter Lang.

Bray, A. (2004) Hélène Cixous: Writing and sexual difference. Palgrave MacMillan.

Chambers, C. (2008). Where are we? Finding common ground in a curriculum of place. Journal of the Canadian Association for Curriculum Studies. 6(2), 113-128. https://jcacs.journals.yorku.ca /index.php/jcacs/issue/view/864/showToc

Chambers, C., Hasebe-Ludt, E., Leggo, C., \& Sinner, A. (Eds.). (2012). A heart of wisdom: Life writing as empathic inquiry. Peter Lang.

Cixous, H. (1976). The laugh of the medusa (K. Cohen \& P. Cohen, Trans.). Signs, 1(4), 875-893. (Original work published 1975)

Cixous, H. (1991). "Coming to writing" and other essays (D. Jenson, Ed.; S. Cornell, D. Jenson, A. Liddle, \& S. Sellers, Trans.). Harvard University Press. (Original work published 1977)

Cixous, H. (2008). White ink: Interviews on sex, text, and politics (S. Sellers, Ed.). Columbia Press.

Cixous, H. (2009). So close (P. Kamuf, Trans.). Polity. (Original work published 2007)

Cixous, H. (2012). Eve escapes: Ruins and life (P. Kamuf, Trans.). Polity. (Original work published 2009)

Hasebe-Ludt, E., Chambers, C., \& Leggo, C. (2009). Life writing and literary métissage as an ethos for our times. Peter Lang.

Hasebe-Ludt, E., \& Jordan, N. (Eds.). (2010). Opening-May we get us a heart of wisdom: Life writing across knowledge traditions. The Journal of Transnational Curriculum Inquiry, 7(2), 1-4. https://ojs.library.ubc.ca/index.php/tci/article/view/2035

Jordan, N. (2011). Inspiriting the academy: Weaving stories and practices of living women's spirituality [Doctoral dissertation]. University of British Columbia Theses and Dissertations. https://open.library.ubc.ca/cIRcle/collections/ubctheses/24/items/1.0072473

Jordan, N. (2013). Goddess puja in California: Embodying contemplation through women's spirituality education. Paideusis: Journal of the Canadian Philosophy of Education Society, 21(1), 13-25. http://www.contemplativeeducation.ca/special-issues-of-paideusis/

Jordan, N. (2016). Daughter of writing: Mother writ large with Hélène Cixous. The Journal of the Motherhood Initiative for Research and Community Involvement, 7(2), 94-104. https://jarm. journals.yorku.ca/index.php/jarm/article/view/40366

Jordan, N. (Ed.). (2017). Placenta wit: Mother stories, rituals and research. Demeter.

Jordan, N. (2018). Placental thinking for mother-centred birth. The Journal of the Motherhood Initiative for Research and Community Involvement, 9(2), 115-126. https://jarm.journals. yorku.ca/index.php/jarm/article/view/40513

Jordan, N. (2019). From Paris to Belfast: A Canadian life writing journey home. In B. Andrews (Ed.), Perspectives on arts education research in Canada (pp. 1-18). Brill/Sense.

Lange, E. (2004). Transformative and restorative learning: A vital dialectic for sustainable societies. Adult Education Quarterly, 54(2), 121-139. https://doi.org/10.1177/0741713603260276 
Ma, V. (2015). The tantric dance of feminine power in the fourth wave of feminism. In M. Robbins Dexter \& V. Noble (Eds.), Foremothers of the women's spirituality movement: Elders and wayshowers (pp. 225-234). Teneo.

O'Reilly, A. (2016). Matricentric feminism: Theory, activism, and practice. Demeter.

Pearce, L. (2016). Burning woman. Womancraft.

Pearce, L. (2018). Medicine woman: Reclaiming the soul of healing. Womancraft.

Pinar, W. F. (2006). The synoptic text today and other essays: Curriculum development after the reconceptualization. Peter Lang.

Pinar, W. F. (2009). The worldliness of a cosmopolitan education: Passionate lives in public service. Routledge.

Pinar, W. F., \& Grumet. M. (1976). Towards a poor curriculum. Kendall-Hunt.

Valora, M. (Ed./Curator). (2008). Carol Rama: The eyes of eyes. Skira Editore.

van der Meer, A. (circa 2011). The language of MA, the primal mother: The evolution of the female image in 40,000 years of Venus art. Demeter.

Vaughan, G. (1997). For-giving: A feminist critique of the exchange economy. Anomaly Press.

Vaughan, G. (Ed.). (2007). Women and the gift economy: A radically different worldview is possible. Inanna.

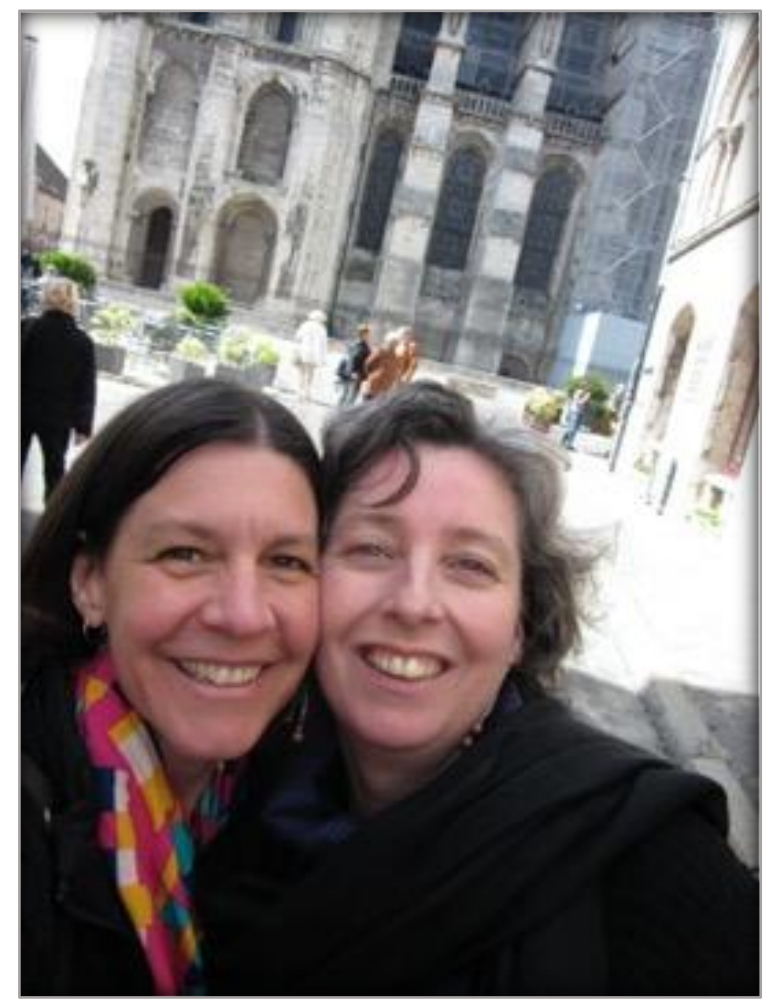

Nané and Barbara outside of Chartres Cathedral, Chartres, France. Selfie by Authors. 